\title{
Histological Development of Selected Neural Structures of Dark-Sided Chorus Frog, Microhyla heymonsi (Amphibia: Anura)
}

\author{
Joan Tang May Yin ${ }^{1^{*}}$, Durriyyah Sharifah Hasan Adli ${ }^{2}$ and Daicus Belabut ${ }^{3}$ \\ ${ }^{12}$ Division of Biohealth Science, ${ }^{3}$ Division of Ecology and Biodiversity, Institute of Biological Sciences, Faculty of \\ Science, University of Malaya, 50603 Kuala Lumpur. Joan_tmy@yahoo.com (corresponding author). \\ Received on $2^{\text {nd }}$ February 2010, accepted in revised form $18^{\text {th }}$ March 2010.
}

\begin{abstract}
The development of selected neural structures of Dark-sided Chorus Frog, Microhyla heymonsi, from tadpole to adult was characterized from the histological aspect. Six developmental stages studied were the early tadpole, pre-metamorphosis, pro-metamorphosis, metamorphic climax, froglet and the adult. For M. heymonsi, metamorphosis is part of a normal developmental process, during which it undergoes transition from an aquatic tadpole into a terrestrial frog. The four neural structures focused on were: (a) cerebral hemispheres of the forebrain, (b) optic lobe of the midbrain, (c) medulla oblongata of the hindbrain, and (d) spinal cord. The specimens were processed for visualization according to $H \& E$ histological staining technique. The observed histological changes and the increase in size of each neural structure were in turn correlated to the external morphology and behaviour of different stages of the developing $M$. heymonsi. Changes in the cellular distribution, especially in the area surrounding the ventricle and other specific changes of the selected neural structures are reported. Apart from that, results also showed changes in the ventricular shape and/or size of each structure. All the apparent changes detected, possibly, represented the maturation of the neural structures in correlation to the metamorphosis process. Results from the light microscopy observations are presented in the form of photomicrographs and sketches with highlights of changes of the selected neural structures.
\end{abstract}

ABSTRAK Perkembangan struktur-struktur saraf tertentu bagi Katak Padi Rusuk-hitam, Microhyla heymonsi telah dicirikan dari aspek histologi. Enam peringkat perkembangan yang telah dikaji meliputi peringkat berudu awal, pra-metamorfosis, pro-metamorfosis, metamorfosis klimaks, katak kecil dan katak dewasa. Untuk M. heymonsi, metamorphosis merupakan sebahagian proses perkembangan dalam kitar hidupnya yang melibatkan peralihan peringkat berudu yang bersifat akuatik ke peringkat katak yang hidup di daratan. Empat struktur yang diberikan tumpuan adalah: (a) bahagian serebrum yang dijumpai di otak hadapan, (b) lobus optik yang berada di otak tengah, (c) medula oblongata yang merupakan sebahagian daripada otak belakang dan (d) bahagian korda spina. Spesimen tersebut diproses untuk tujuan visualisasi menerusi teknik pewarnaan H\&E. Perubahan dalam ciri-ciri histologi dan peningkatan saiz struktur-struktur saraf tertentu telah dihubungkaitkan dengan morfologi luaran dan tabiat pada peringkat berbeza. Perubahan dari segi taburan sel-sel khususnya di kawasan sekitar ventrikel dan perubahan spesifik yang lain juga dilaporkan. Selain itu, keputusan juga menunjukkan perubahan dari segi bentuk ventrikel dan/atau saiz bagi setiap struktur. Perubahan nyata yang dapat diperhatikan berkemungkinan mewakili struktur saraf yang matang. Keputusan daripada pemerhatian mikroskopik cahaya dibentangkan dalam bentuk fotomikrograf dan lakaran.

(Keywords: Dark-sided Chorus Frog, Microhyla heymonsi, neural structures, histological development)

\section{INTRODUCTION}

Information regarding studies done on the nervous tissue of non-mammalians is relatively scarce, owing to the intricacy of processing such tissue in view of the fact that this tissue does not render itself well to histological techniques. Thus, established histological reports involving such tissues are not as abundant as for the diverse reports on mammalian neural tissue. The situation is more critical for the local amphibians, although Malaysia is endowed with rich fauna diversity.

Being one of the smallest local frog species from the Microhylidae family, Microhyla heymonsi (Vogt, 1911) or commonly known as the Dark-sided Chorus Frog [1] can be easily distinguished due to its distinctive black lateral bands at the sides of the head $[2,3]$. Similarly in other Anurans, the life cycle of this species involves the evolution of aquatic tadpoles 
to the terrestrial adult frog through the prominent process of metamorphosis. The different stages of the tadpole were categorized according to the Taylor and Kollros Classification System which is in regards to the hind length to body length ratio (HL: BL) of the specimens [4][Figure 1]. Six developmental stages, i.e. (a) early tadpole, (b) pre-metamorphosis, (c) prometamorphosis, (d) metamorphic climax, (e) froglet and (f) adult frog, were highlighted in this study [Figure 2].
Focusing on these six stages of its life cycle, the development of four selected neural structures; a) cerebral hemispheres of the forebrain, (b) optic lobe of the midbrain, (c) medulla oblongata of the hindbrain, and (d) spinal cord were characterized from the histological aspect [Figure 3]. This study also serves to highlight the correlation between the development of these neural structures and the external metamorphic changes of the frog throughout its lifecycle.

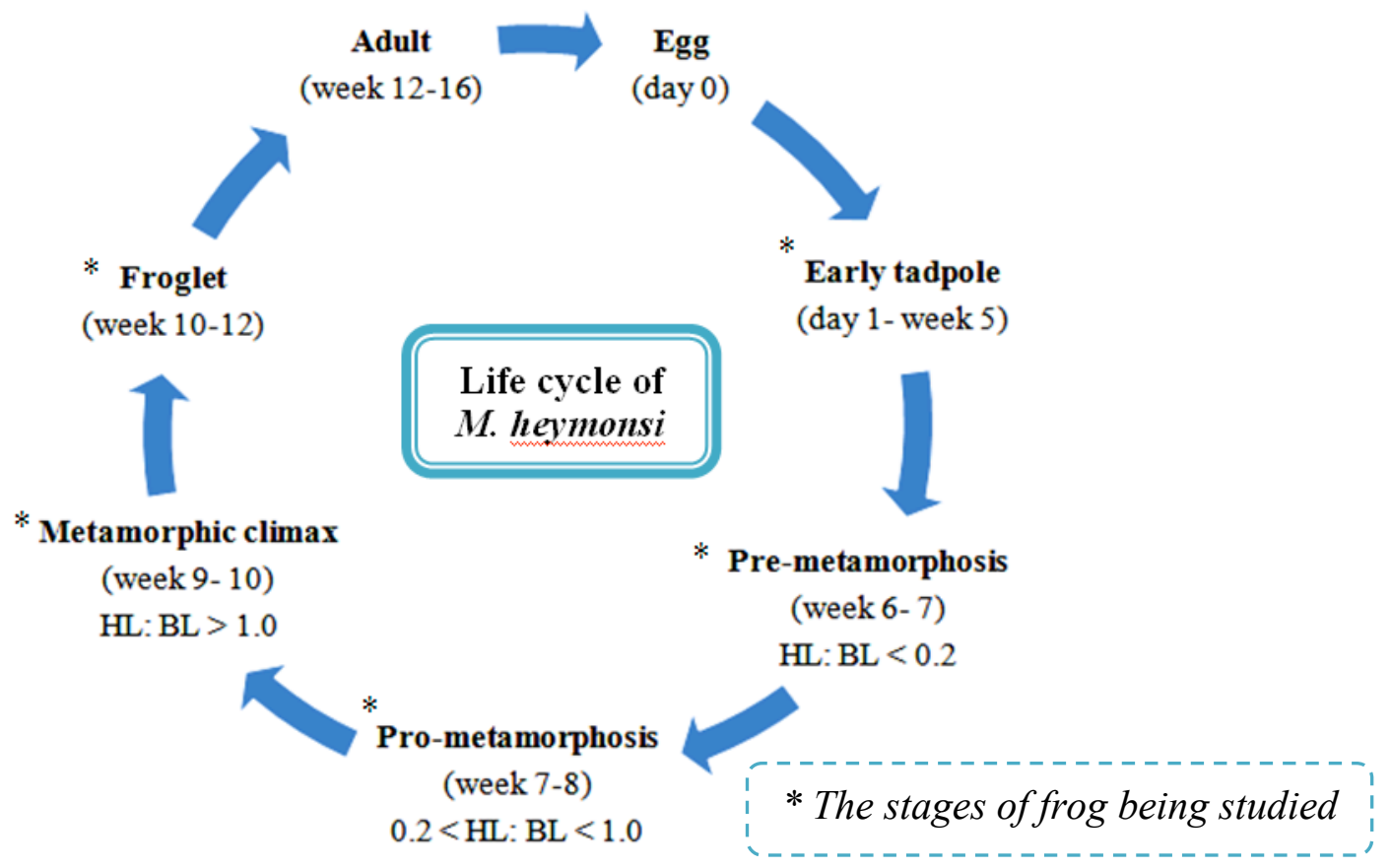

Figure 1: Life cycle of Microhyla heymonsi. The tadpole staging process was based on the Taylor and Kollros Classification System, i.e. Hind length to body length ratio (HL: BL). 


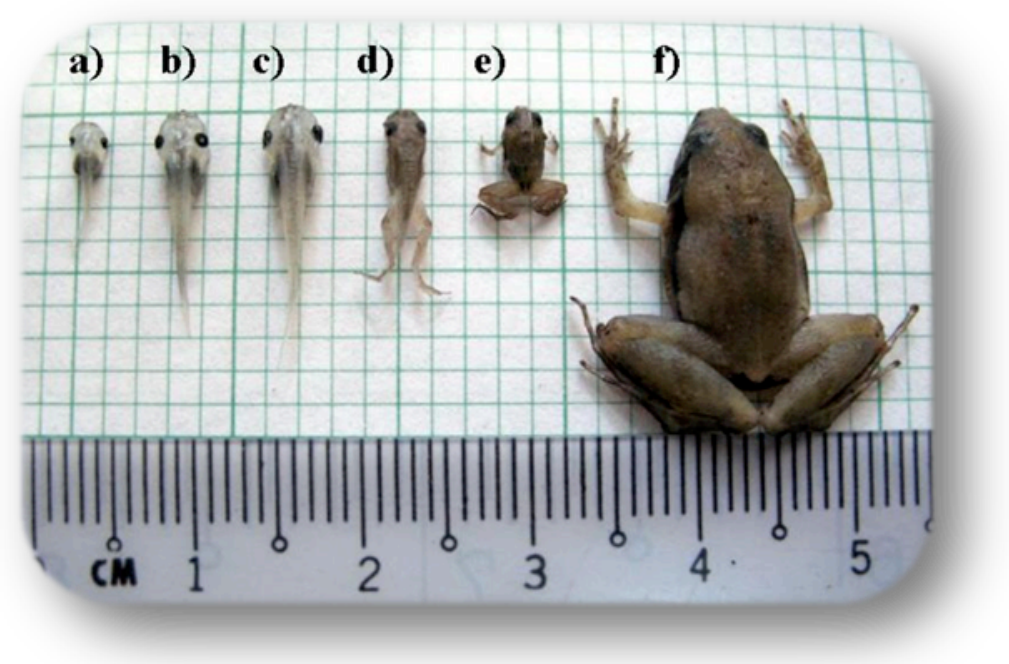

Figure 2: The 6 developmental stages being highlighted; (a) early tadpole, (b) pre-metamorphosis, (c) prometamorphosis, (d) metamorphic climax, (e) froglet and (f) adult frog.

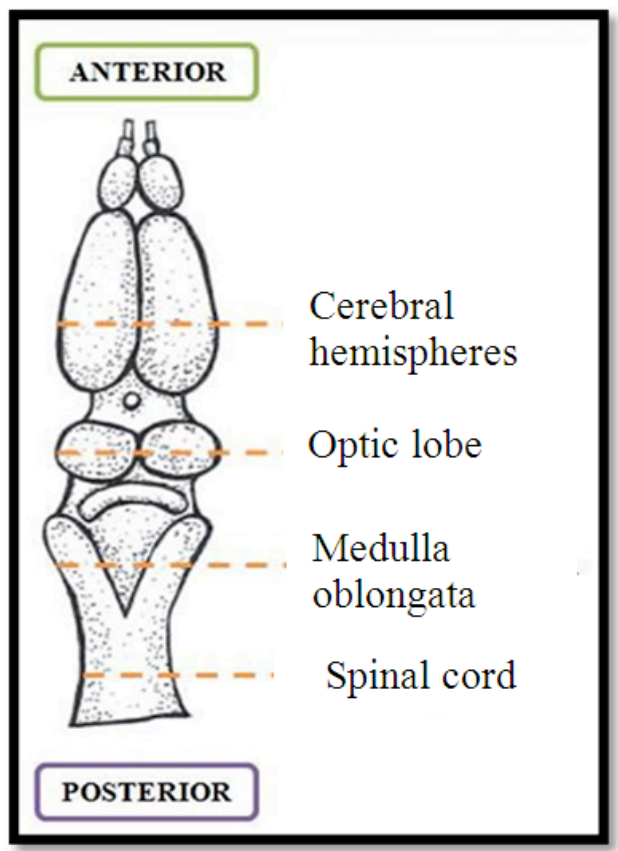

Figure 3: Dorsal view of adult frog's brain showing the four levels of selected neural structures being studied [5].

\section{MATERIALS AND METHODS}

Specimens were acquired and reared for the purpose of obtaining the specific stages as mentioned before. Throughout the period of rearing, the experimental animals were observed and measured in order to aid the staging process. The specimens were subsequently processed according to the histological procedures which include several steps; (a) fixation of tissue in $10 \%$ formalin to avoid cell degradation, (b) dehydration to remove water from the tissue sample by transferring the specimens sequentially to a series of alcohol solution with ascending concentrations, (c) clearing which involved the process of removing the remaining alcohol in the tissue by using toluene as clearing agent, (d) infiltration and embedding in paraffin producing blocks of tissue, (e) sectioning of the paraffin blocks by using a microtome and thus producing serial ribbons of tissue sections measuring $8 \mu \mathrm{m}$ each, (f) mounting of tissue sections onto glass slide and finally (g) staining in accordance to the H\&E staining 
technique. Light microscopy observation of the stained slides were then conducted, followed by capturing of photomicrographs prior to the final step

\section{RESULTS AND DISCUSSION}

Representative transverse sections (TS) of the selected neural structures comprising the cerebral hemispheres, optic lobe, medulla oblongata and spinal cord from six different stages of development were emphasized.

\section{Histological Development of the Cerebral Hemispheres}

As growth progressed, the cerebral hemispheres showed an apparent increase in size. Aside from that, this structure developed changes in term of shape where the uniform circular-shaped of the hemispheres in the early stages became elongated in the dorsal region as seen in the froglet and adult

\section{Histological Development of the Optic Lobe}

The main divisions of the optic lobe were the dorsal tectum where protrusion is visible, and the basal tegmental portion as has been reported before [6]. Apart from size increment and changes in the shape of ventricle of the optic lobe, the presence of torus semicularis and lamination of the optic tectum, though the layers were not clearly distinguishable, were seen in adult frog. Cell bodies remained concentrated around the area surrounding the ventricles in all stages but the intensity of darkly stained area especially in the tegmentum region was reduced in the adult stage.

Coordination between vision and action of the animal relies on the function of the optic lobe. The dorsallylocated optic tectum is crucial in the integration of the visual system for executing the 'prey-catching' and saltatory movements such as jumping, hopping and leaping as well as the grasping reflex, produced by the male adult frog during mating. Conversely, the tegmentum transmits motor impulses to the spinal cord and controls the locomotion.

Histological Development of the Medulla Oblongata The most posterior part of the brain, the medulla oblongata was slightly widened and flattened in appearance [7]. The developmental changes of this structure were not clearly noticeable as seen in Figure 6 , apart from apart from the broadening of the dorsal portion of medulla oblongata and the changes in the cell bodies distribution which was progressively decreased in the older stages. of data interpretation and analysis utilizing the 'Analysis LifeScience Soft Imaging System' software.

stages. In addition, changes in the shape of the lateral ventricles were also observed. The ventricles initially widen horizontally in the first 3 stages before lengthening vertically in the final three stages. In terms of cell distribution, most of the cell bodies which contain nuclei were highly concentrated in the area surrounding the ventricles especially in the early stages. Conversely, this distribution of cells was reduced in the adult frog as lesser intensity of darkly stained area was visualized.

This structure was concerned with the olfactory integration as impulses from olfactory fibers were received by all parts of the cerebral hemispheres. Thus the development was possibly due to its need for predation especially when the frogs go into the terrestrial behaviour.

This structure regulates the vital physiological functions such as respiration, heart rate, and blood pressure. These subconscious activities are essential for the survival of every organism. The morphological and histological development observed in the six stages involved could be correlated to the changes in the control over the respiration system i.e. from gills to lungs, and the circulatory system as the heart develops the 3rd chamber as it reaches metamorphosis.

\section{Histological Development of the Spinal Cord}

From Figure 7, the histological development of the spinal cord involved the increase of size, changes in the shape of structure and the dispersal of cell bodies as the tadpole evolved into adult frog. The diameters of the central canal were visibly declining as the tadpoles grew. The biggest central canal is at its widest in the pre-metamorphosis stage while the smallest shown in the adult stage. The decrease can be linked to the obliteration by proliferation of ependymal cells and astrocytes. The grey matter was gradually reduced and the typical 'H-shape' structure took its form in the adult stage whereas the area of white matter was evidently increasing as the tadpole developed into mature stages.

The spinal cord, in short, serves two functions: to transmit impulses to and from the brain and secondly, to act as a reflex center. Therefore, its development could be associated to the transition of locomotion method from swimming or undulating with the tail in aquatic tadpole to saltatory movement which requires the coordination of both fore- and hind limbs. Thus, the complex movements like jumping and leaping 
movements could be seen in the stages after metamorphosis.

\section{Overall Changes in the Selected Structures}

Throughout the six developmental stages, all 4 neural structures: the cerebrum, optic lobe, medulla oblongata and the spinal cord, showed an apparent increase in term of size. This is in part related to the growing size of the body as additional organs and greater muscle mass require more controlling mechanisms [8]. Moreover, changes were also observed in the shape of in these neural structures as well as the ventricles. This could be a result of the differential growth of various areas within the neural structures. Another obvious difference in these neural structures as growth progressed was the changes in cell bodies distribution. This could be accounted for the constant generations of new cells which are required for growth and development. However, the distribution of neuronal soma gradually reduced in the later stages as shown by the decreasing intensity of darkly stained area present around the ventricle particularly in the adult stage. There are two possibilities to be taken into consideration: (a) migration of cells to other regions from the areas adjacent to the central canal in the spinal cord or near the ventricles in the brain. One mechanism which has been put forward is neurons migrating to their positions in the maturing nervous system along glial cell scaffolding. (b) death or de-functionalization of unused neurons.

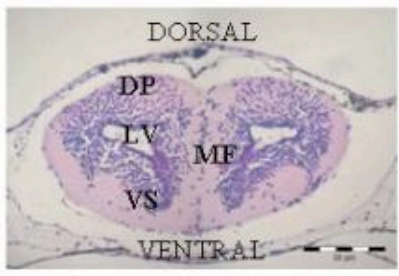

a) Early tadpole

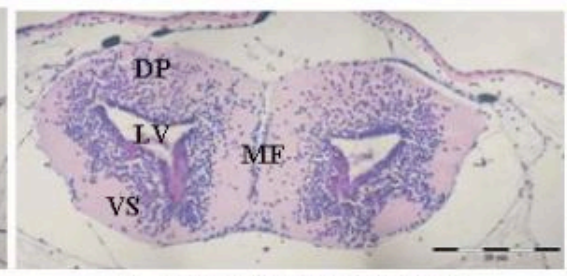

b) Pre-metamorphosis

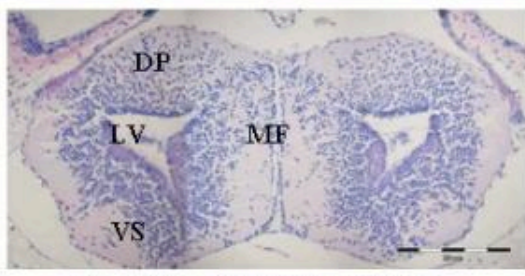

c) Pro-metamorphosis

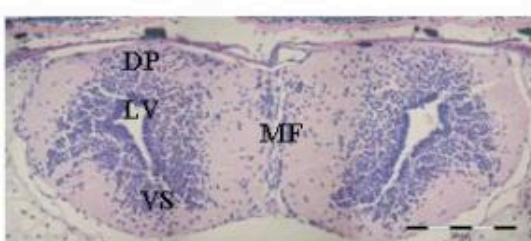

d) Metamorphic climax

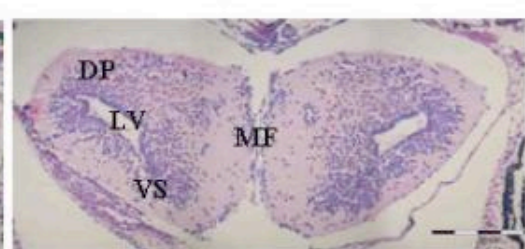

e) Froglet

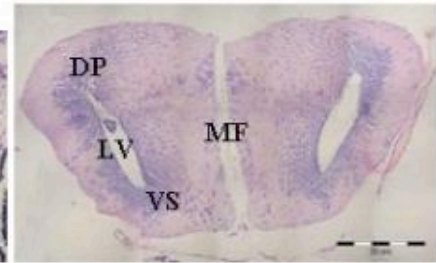

f) Adult frog

LV: Lateral ventricle; MF: Median fissure; DP: Dorsal pallium; VS: Ventral subpallium)

Figure 4: Transverse sections (TS) of the cerebral hemispheres for 6 developmental stages of frog, under $100 \times$ magnification 


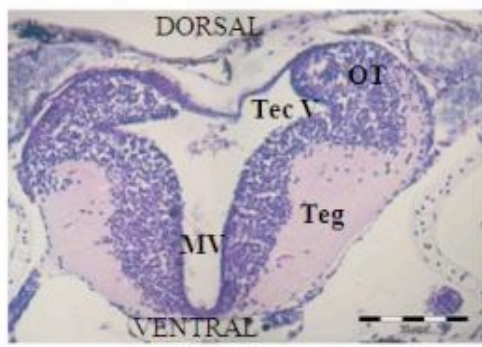

a) Early tadpole

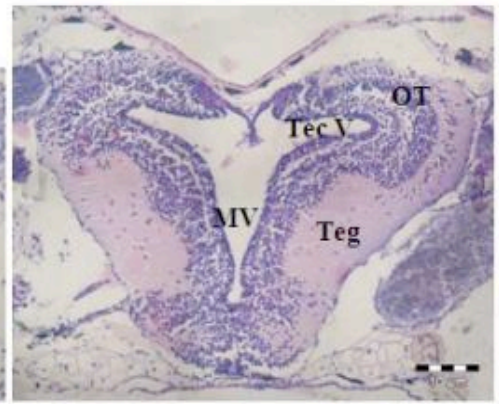

b) Pre-metamorphosis

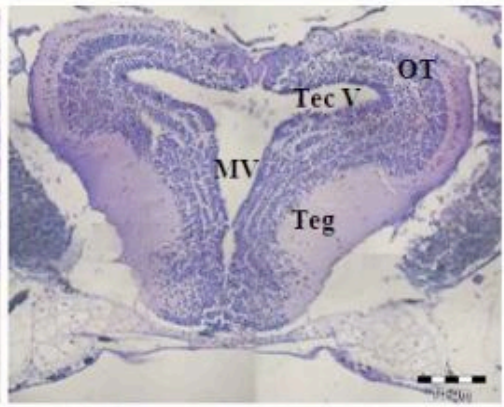

c) Pro-metamorphosis

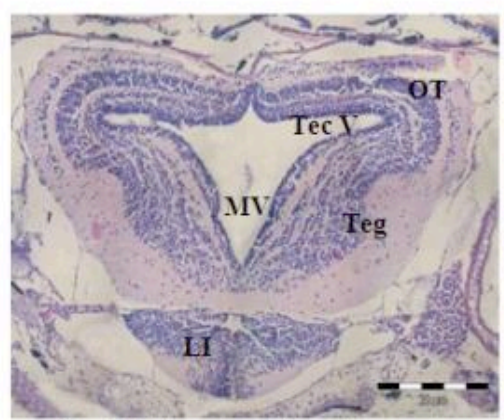

d) Metamorphic climax

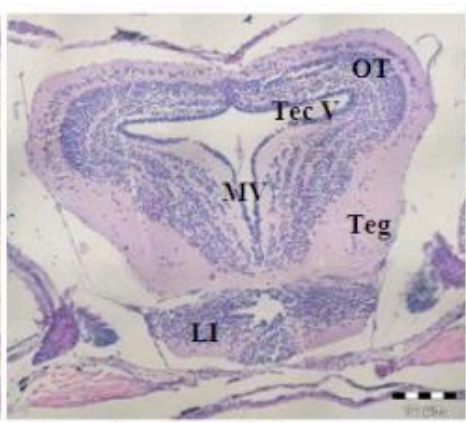

e) Froglet

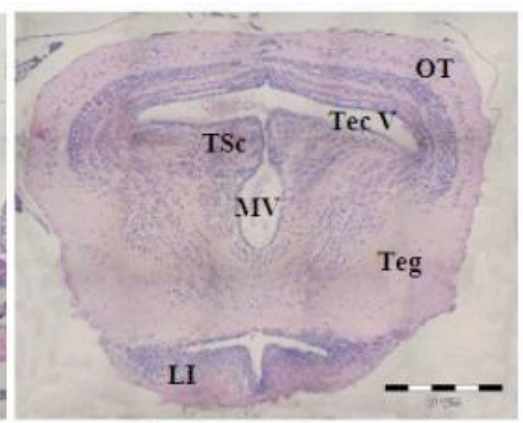

f) Adult frog

OT: Optic tectum; Teg: Tegmentum; MV: Mesencephalic ventricle; Tec V: Tectal ventricle; LI: Lobus infundibularis; TSc: Torus semicularis

Figure 5: Transverse sections (TS) of the optic lobe for 6 developmental stages of frog, under $100 \times$ magnification

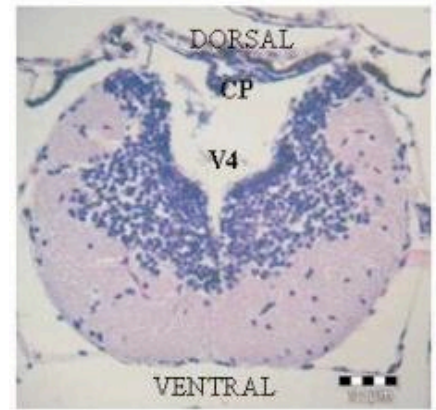

a) Early tadpole

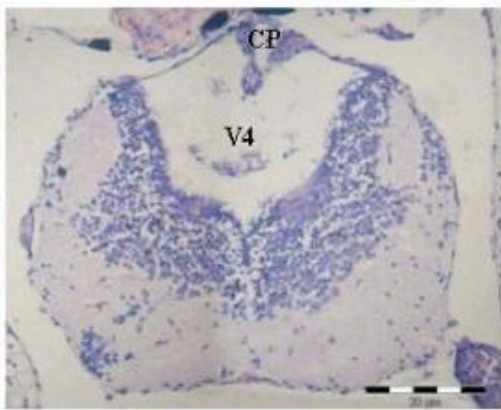

b) Pre-metamorphosis

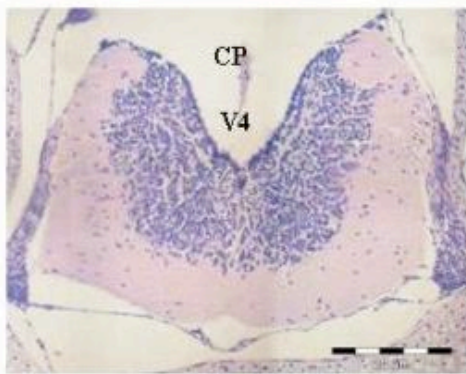

d) Metamorphic climax

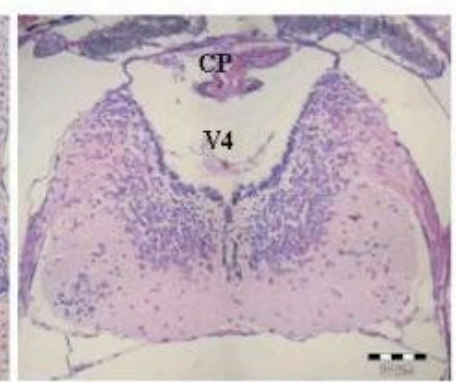

e) Froglet

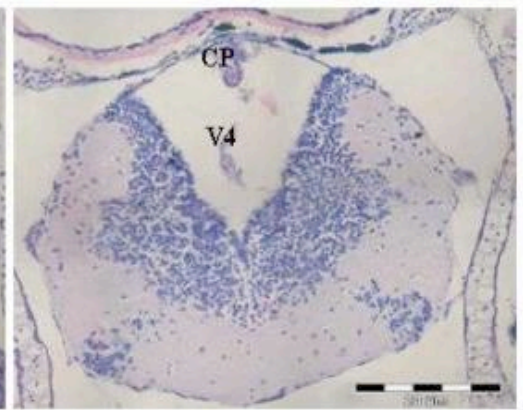

c) Pro-metamorphosis

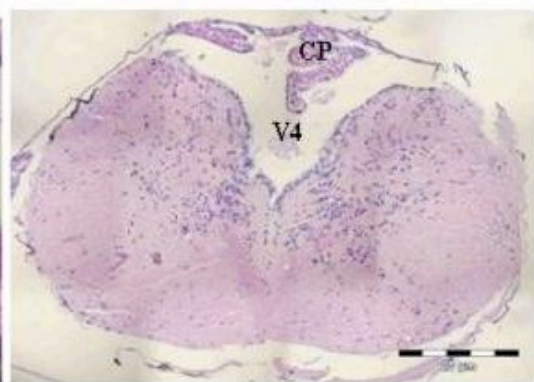

f) Adult frog

CP: Choroid plexus; V4: Fourth ventricle; Ep: Ependyma

Figure 6: Transverse sections (TS) of the medulla oblongata for 6 developmental stages of frog, under 100× magnification 


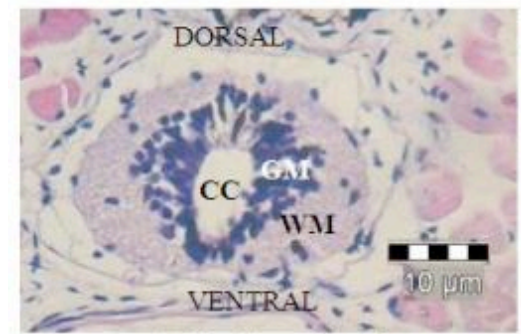

a) Early tadpole

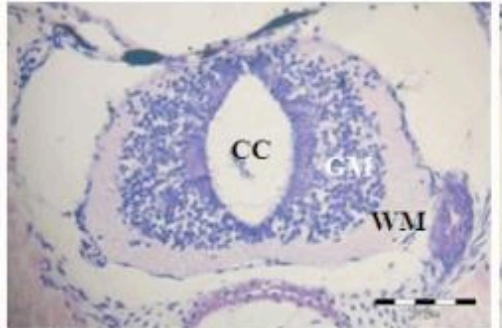

b) Pre-metamorphosis

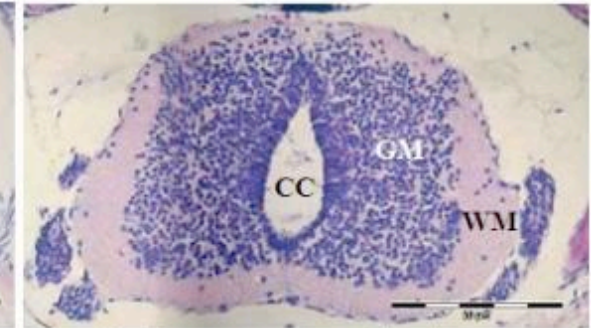

c) Pro-metamorphosis

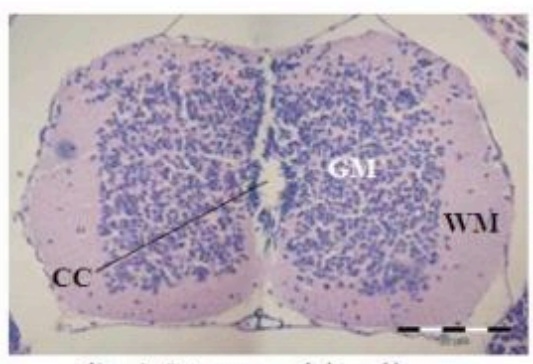

d) Metamorphic climax

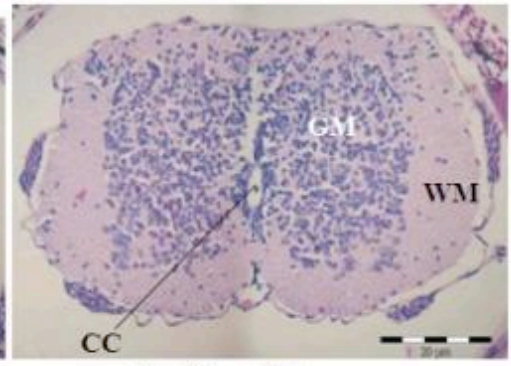

e) Froglet

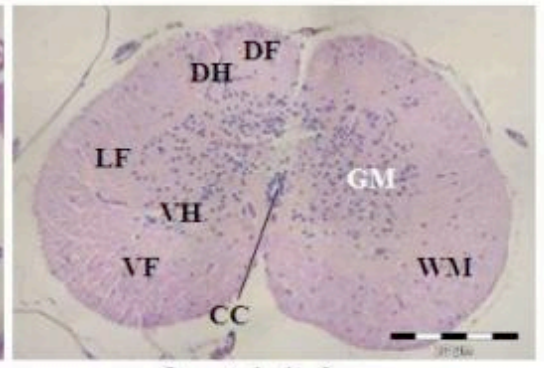

f) Adult frog

CC: Central canal; GM: Grey matter; WM: White matter; DH: Dorsal horn;

VH: Ventral horn; DF: Dorsal funiculus; VF: Ventral funiculus; LF: Lateral funiculus

Figure 7: Transverse sections (TS) of the spinal cord for 6 developmental stages of frog, under $100 \times$ magnification

\section{CONCLUSION}

In general, the neural structures showed histological changes throughout the six developmental stages of Microhyla heymonsi being investigated. These changes could be correlated to the development from an aquatic tadpole to a terrestrial frog.

\section{ACKNOWLEDGEMENT}

This research was partly funded by Universiti Malaya teaching grant. To Madam Puah Lin Eng of Makmal Microhistoteknik ISB for the guidance especially on histological techniques.

\section{REFERENCES}

1. Lim, K.K.P. \& Lim, F.L.K. (1992). A Guide to the Amphibians and Reptiles of Singapore. Singapore, Singapore Science Centre

2. Berry, P. Y. (1975). The Amphibian Fauna of Peninsular Malaysia. Tropical Press, Kuala Lumpur.
3. Parker, H. W. (1966). A Monograph of the Frogs of the Family Microhylidae. Johnson Reprint Corp., New York.

4. Rohaya binti Mamat. (1996). Perkembangan sistem saraf pusat katak tempatan, Polypedates leucomystax (Boie) dari peringkat berudu ke peringkat dewasa. Tesis Ijazah Sarjana Muda Sains. Jabatan Zoologi, Fakulti Sains, University Malaya, Kuala Lumpur, Malaysia.

5. Webb, J. E., Wallwork, J. A. and Elgood, J. H. (1981). Guide to Living Amphibians. The Macmillan Press Ltd, Hong Kong.

6. Lofts, B. (Ed.) (1915). Physiology of the Amphibia (Vol. III). Academic Press, New York.

7. Noble, G. K. (1954). The Biology of Amphibian. Dover Publication, New York.

8. Sarnat, H. B. and Netsky, M. G. (1981). Evolution of the Nervous System (2nd Ed.). Oxford University Press, New York.

9. Llinás, R. and Precht, W. (1976). Frog Neurobiology: A Handbook. New York, Springer-Verlag. 